\title{
Stitching Together Meaning: Sarah Jane Kimball's Fancywork, Class, and Consumption in Late Nineteenth-Century Iowa
}

\author{
MiCHAEL LEWIS
}

ON A BRIGHT LATE-SUMMER SUNDAY in 1899, Sarah Jane Kimball prepared her home for a visit from the local "Artist" she had commissioned to make a series of photographs of the family and the house. She had cleaned all morning and made sure that her dinner dishes had been cleared and her house well ordered by the afternoon of the scheduled appointment. On the first visit, the artist photographed none of the family members. Instead, he focused on the house, especially the parlor. Over the next six weeks, the photographer returned to the family home five more times to take additional pictures of the house, the parlor, and, finally, the three family members, although they were still positioned to show off the parlor and sitting room to best advantage. ${ }^{1}$

For the "artist," the repeated trips out to the Kimball farmnearly six miles each way on a dusty dirt road from the small town of Wyoming, Iowa-apparently were not entirely odious. Kimball's diaries relate that as she became more "familiar" with the photographer, he began to enjoy lunches on his visits, in addition to Kimball's always generous hospitality. As evidence of their growing familiarity, Kimball modified the photographer's

1. Sarah Jane Kimball, Diary, 17 and 24 September and 1, 8, 22, and 29 October 1899, Sarah Jane Kimball Papers, State Historical Society of Iowa, Iowa City.

THE ANNALS OF IOWA 59 (Spring 2000). (C) The State Historical Society of Iowa, 2000. 
name (at least in her diary) from "the Artist" to "the Artist Lee," and finally just "Lee." Not surprisingly, Lee was able to discern what types of pictures his client would value, and he successfully captured what Kimball found important in her home and family. In early November Kimball picked up her finished photographs and, in a diary that often avoided the mention of specific prices, noted that she had paid $\$ 18.05$ (equivalent to about $\$ 350$ in 1999 dollars) for the pictures. More significantly, she added that she was "well pleased" with them. ${ }^{2}$

Of the nine photographs, three are house exteriors, three house interiors, and three are interior group portraits of Kimball, her unmarried brother Merrill, and their father (Kimball's mother was dead by this time). ${ }^{3}$ The photographs of the house exterior showed a fairly large, two-story home, freshly painted, with nicely decorated eaves-work. Grass evenly covered the yard, flowers were neatly arranged in gardens, and there was even a small glass greenhouse in which Kimball kept her most special flowers.

It is the interior of the home that is truly striking, however. As was typical in Victorian homes, Kimball had decorated her parlor in spectacular complexity with products she had accumulated over more than 30 years since she had begun doing fancywork shortly after the Civil War. ${ }^{4}$ Pictures lined the walls, knick-knacks covered the shelves, and a homemade garland of leaves looped gracefully where the wall met the ceiling, outlining windows, and trailing down corners. The floor was covered with tables holding yet more objects, and Kimball had propped two-dimensional wooden cutouts of dogs, farmers, and cats against the bottom of the walls. The frames of the many pictures were a hodgepodge of seeds, dried flowers, leaves, and shells. With the exception of the actual pictures, these items were handmade - most, we may assume through reading her diaries,

2. Kimball Diary, 29 October and 5 November 1899 . The cost comparison is based on data from the Consumer Price Index statistics from Historical Statistics of the United States (Washington, DC, 1975); and U.S. Bureau of the Census, Statistical Abstracts of the United States, 1999 (Washington, DC, 1999).

3. The photographs are in the Kimball Papers (see following pages).

4. Nancy Bercaw, "Solid Objects/Mutable Meanings," Winterthur Portfolio 26 (1991), 231. 


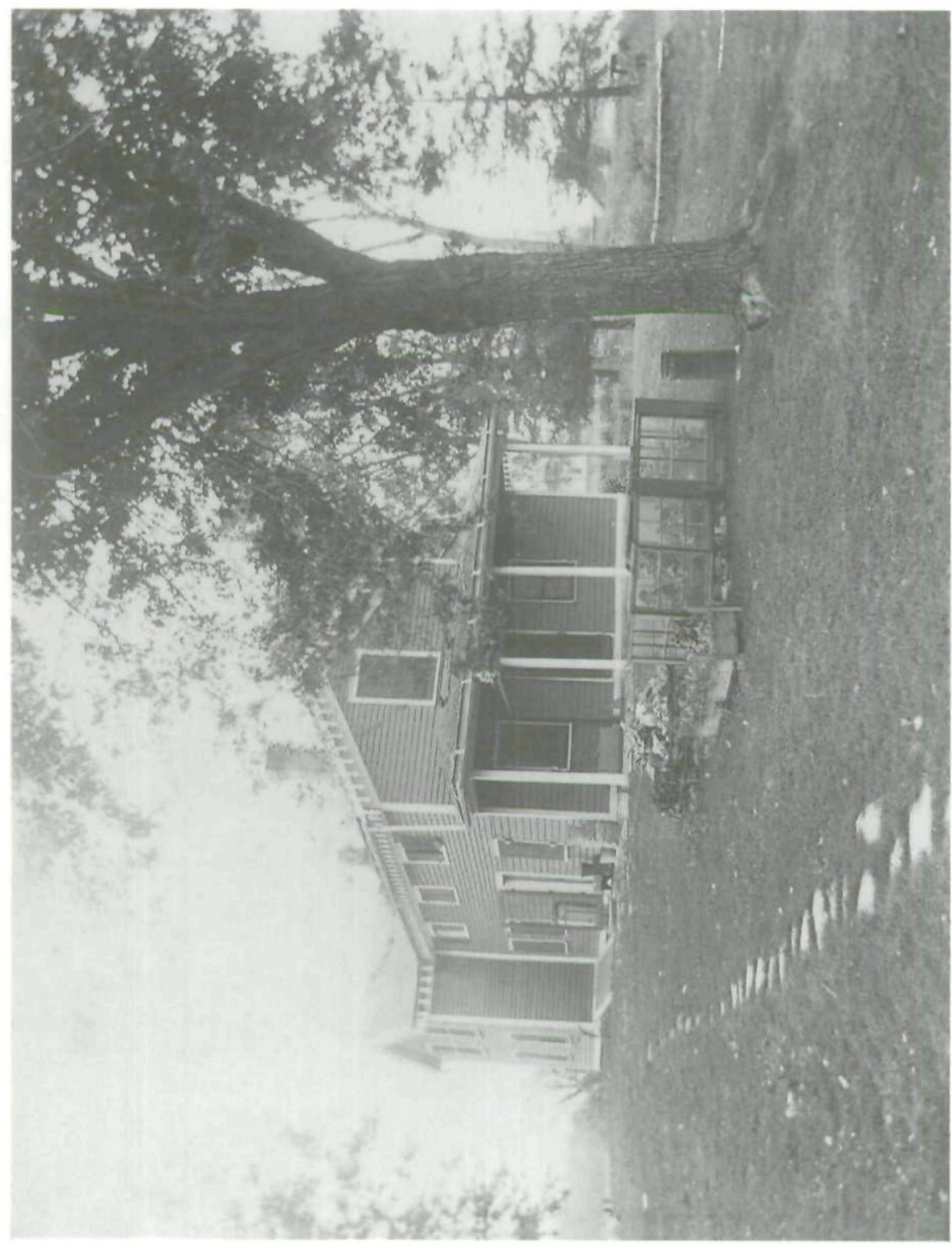




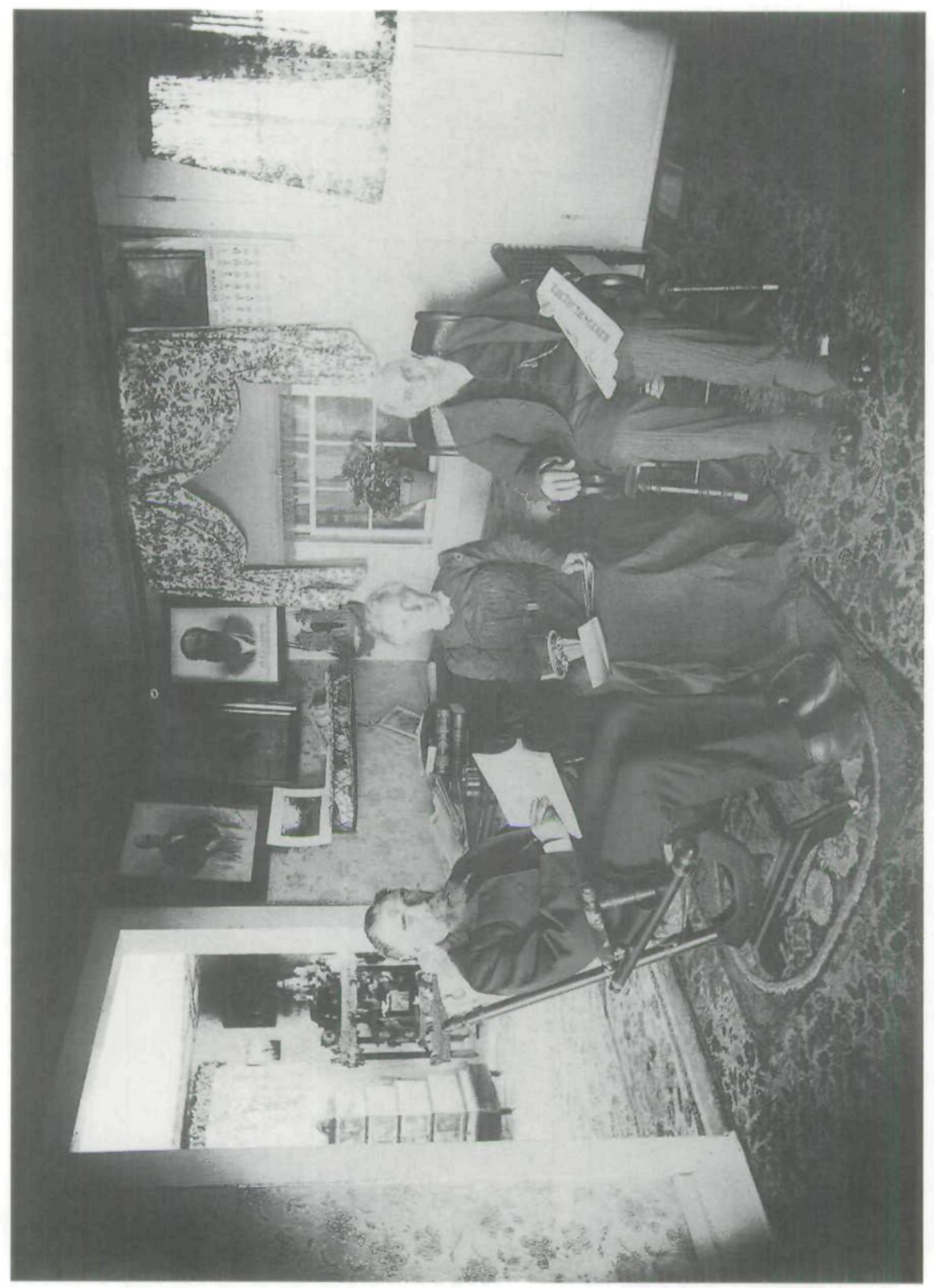




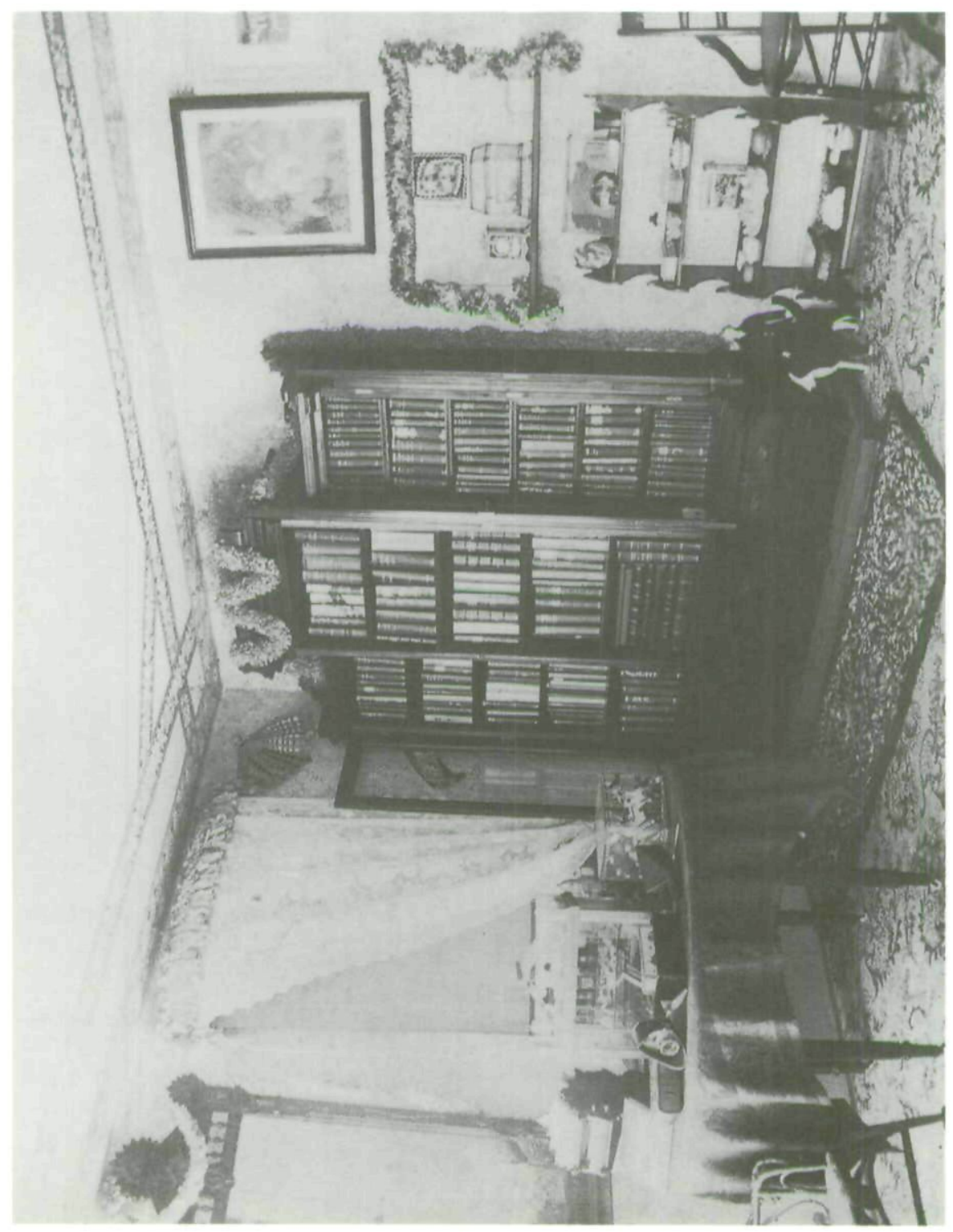




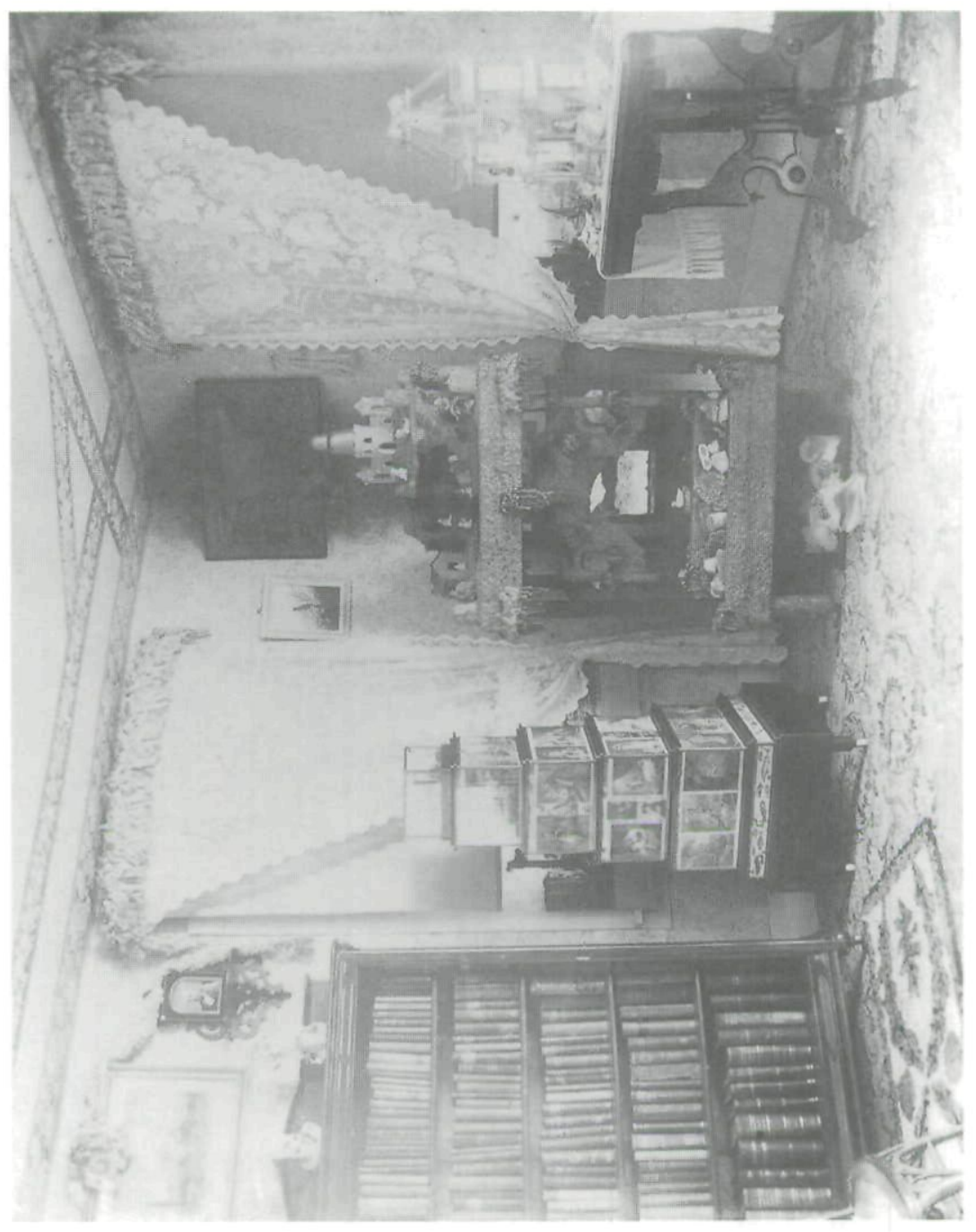




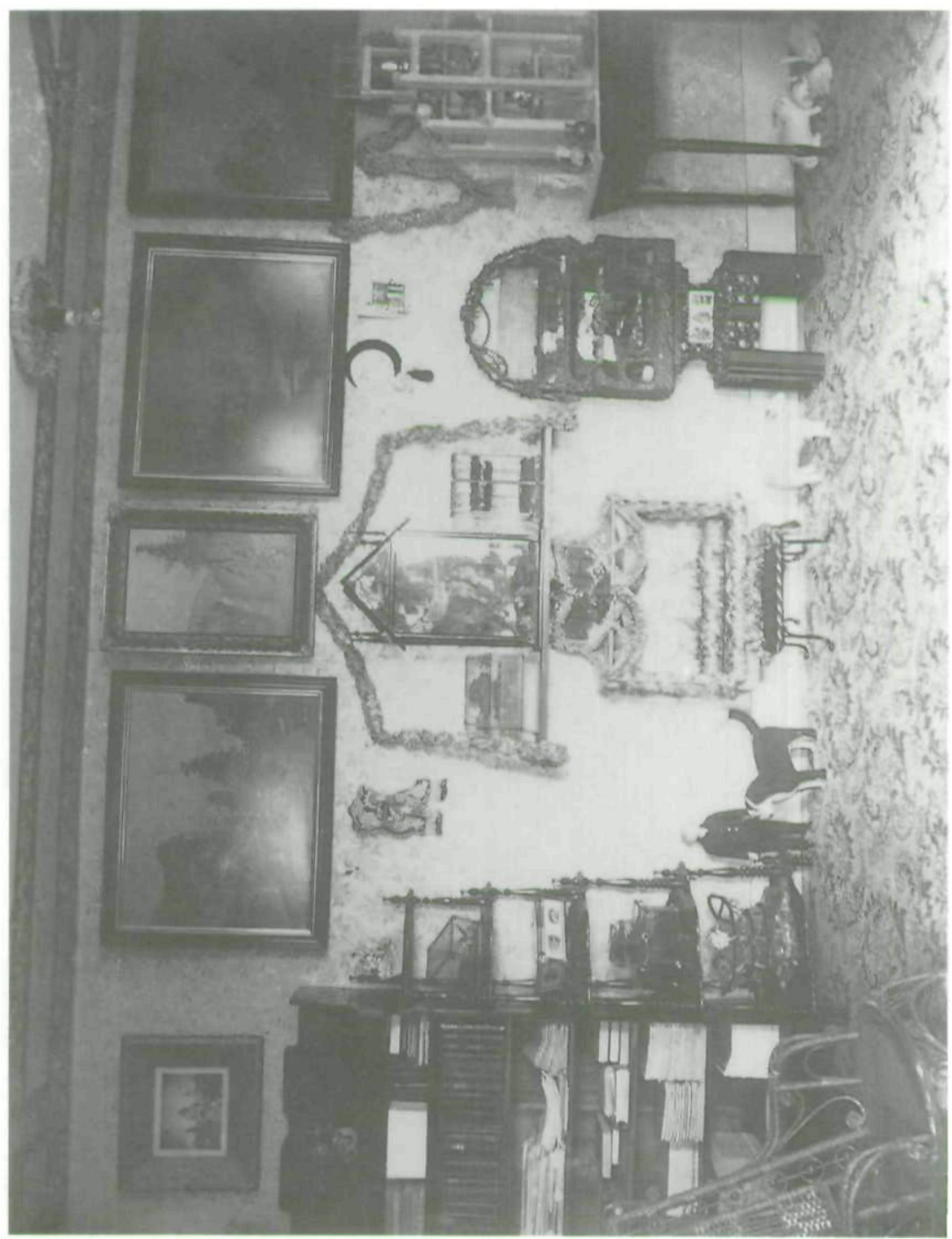


by Kimball herself. Interspersed between the many craft objects (fancywork, as it was called) were such products of the late nineteenth-century catalog culture as a melodeon (so beloved that it was used to play songs for the funeral of Sarah's mother), a stereoscope, and shelves of books. To present-day viewers, the parlor is somewhat visually overwhelming. To Kimball, her family, and the photographer, however, it was highly appropriate. The Artist Lee even positioned the family in the portraits to show the interior decorations to good effect.

These photographs of Kimball's fancywork and parlor illustrate more than just local tastes or rural visions of aesthetic beauty. In conjunction with Kimball's diaries, they provide an opportunity to consider the relationship between the material objects of Kimball's parlor and the changes occurring in her family's economic status, in her own life and her role in her family, and in larger patterns of consumerism and industrialization in Iowa and the United States. ${ }^{5}$ Between 1865 and 1875, Sarah Jane Kimball, drawing on domestic ideals formulated in the more urban East, created a material universe that meshed with her vision of proper domestic interiors, and she continued to display her creations for the next quarter-century. In so doing, Kimball established her family and home as solidly "middle class." Creating that material universe also helped her define her identity and her role in her family after she abandoned her schoolteaching career without leaving home to marry and establish her own family. Finally, Kimball's material universe con-

5. The Sarah Jane Kimball Papers at the State Historical Society of Iowa comprise the nine photographs, a few letters, some of Sarah's writings and drawings, her teaching certificates, and other miscellaneous items. The diaries, however, form the heart of the collection. Kimball began her diary with one entry in 1854 and another in 1856. She began regular entries in 1857 and continued until 1912. A separate volume, titled "Some of My Experiences Teaching School," was partly a diary and partly drew on separate diary entries to create a narrative of her teaching experiences from 1862 through 1868. In 1953 Sister Mary Irma Corcoran, B.V.M., prepared a typed transcription of that volume, with quotations from the separate diaries inserted. The transcription, titled "Sarah Jane's Journal (1854-1868): The Life Record of a Country School Ma'am during the 'Sixties,'" was apparently never published. Corcoran admitted to "thin[ning] out the underbrush" (iv) of reiterated weather reports, lists of visitors, and the like. When I have cited material that is included in this transcription, I have included the relevant page number. 
sisted of not just homemade crafts, but objects purchased from catalogs as well. The presence of such objects calls into question the assumption that only "homemade" fancywork is an "authentic" reflection of personal identity and meaning. These three themes, then-the relationship between Kimball's fancywork and her vision of class, her self-definition as a respectable woman, and her catalog consumption-provide the focus for this portrait of Kimball's, and Iowa's, late nineteenth-century past.

SARAH JANE KIMBALL spent most of her life in the Midwest, although she was born in Massachusetts in 1838 as the eldest child of a mother who had worked in the Lowell textile mills and a father who could trace his roots back to a Puritan immigrant in the 1600s. The Kimball family had moved to Greene County, Wisconsin, in 1843, when Sarah was five. By 1856, when Sarah was 18 (and had three brothers and two sisters), unfriendly neighbors and difficulty acquiring sufficient land led the family to move to 180 acres of unimproved land in Jones County, Iowa, about six miles from the nearest small town of Wyoming. They quickly built a small shack and then began the arduous process of imposing their agrarian vision on the land. ${ }^{6}$ As they transformed their land, their home, and their lifestyle, this frontier pioneer family became the family of proud, prosperous midwestern farmers that is portrayed in Artist Lee's photographs on the cusp of a new century.

Thirty-five years before the Artist Lee took those photographs of the Kimballs' parlor, however, Sarah Jane, then in her late twenties, was not nearly as pleased with her home and her place in it. The summer of 1865 was the first summer in four years that she had spent at home rather than teaching the summer session in some nearby school. That summer she was recovering from an illness (which she thought at the time would soon pass, but which proved to linger for four years). Kimball

6. Anonymous two-page biography of Sarah Jane Kimball in the Kimball Papers. For more on Kimball, including a summary of most of her lifetime of journals, see Merrill E. Jarchow, "Life on a Jones County Farm, 1873-1912," Iowa Journal of History 49 (1951), 311-38; and idem, "Social Life of an Iowa Farm Family, 1873-1912," Iowa Journal of History 50 (1952), 123-54. 
did not enjoy this time at home with her mother, father, and younger siblings. As she recorded in a rare emotional outburst in her diary, "I worked hard as I could at every thing I could find to do, and had the satisfaction of having mother tell me I was not half as good as Ann [Sarah Jane's sister] at any kind of work. I didnt quite believe it, though I made up my mind that doing housework for some one else was not my forte, and I resolved that as I liked teaching a great deal better, I should follow it as long as I had the chance..$^{\prime 7}$

Teaching school was one of the few acceptable occupational choices for women in the nineteenth century. ${ }^{8}$ It was hardly a stable career, however. School sessions lasted three to four months, and schools usually hired teachers for one session at a time, so teachers had to be willing to move throughout the area following job offers, and could look forward to only short-term employment. In between each teaching session, Kimball (like many other teachers) would return to live with her family while looking for her next job. Many teachers and employers thought this schedule was particularly well suited to the rhythm of women's lives. A young woman, after all, might get married at any point and discontinue her teaching to raise children and work on a family farm.

During school sessions, teachers roomed and boarded with students' families, usually staying with each family for a week before moving on to the next family. Kimball especially relished the opportunity to see how all kinds of families lived. As she circulated among several Iowa communities, Kimball refined

7. Kimball Diary, Summer 1865, p. 141. This quotation must be understood in the context of her overall diaries. Kimball almost never complained, preferring to put things in the best possible light. When she did, the complaint usually, as in this case, exposed her wit. In one other example, Kimball, who clearly enjoyed visiting and receiving visitors (she almost always recorded such visits as "pleasant"), commented on one visitor who must have bothered her: "Monday Hattie Shaffer came to make an all day visit. I hope she enjoyed it more than I did." Kimball Diary, 15 August 1897. Kimball used the same kind of understated and subtle criticism in her diary that one would use in polite conversation, not using her diary for venting her innermost feelings. In this context, her mild complaint about living at home with her mother appears as very nearly a scream of primal rage.

8. Thomas Morain, "The Departure of Males from the Teaching Profession in Nineteenth-Century Iowa," Civil War History 26 (1980), 161-70. 
her sense of class (what she would usually term as "nice and neat" versus "shabby and dirty"). During the same years she began to use her free time in the evenings to learn how to do various types of fancywork. On February 1, 1862, during her first school term, she recorded her first crafts, making two dolls and dressing them. ${ }^{9}$

THE KIMBALLS, like many families who came to the frontier in search of economic opportunity, aspired to a life of middleclass respectability. Sarah Jane adopted that aspiration wholeheartedly. As early as 1857, in the second entry in her journal, at the age of 18 , Kimball noted that the people she had recently visited were "very dirty folks as their house plainly showed." Her early diary entries also record a keen interest in planting and caring for flowers around her home.

Kimball refined her vision of what constituted a "middleclass" home during her years as an itinerant teacher. By the time she quit teaching to devote herself to "helping" at home, Kimball's experience teaching and living with other families had left a well-formed impression of what constituted a "nice" home. It is apparent from reading her journal that what marked a home as "nice" (and thus sufficiently refined to be included in the middle class) was not size or wealth, but the way it was maintained. In describing one family and house Kimball wrote, "she was a very neat modest woman and there was always a charm about the place which pleased me. One very pleasant evening as I was sitting there with nothing to do Sarah [a child] asked me if I wouldn't make a doll for her. ${ }^{\prime 10}$ Kimball apparently saw a close connection between the qualities that made the home charming and the daughter's request for a homemade doll. Again and again, Kimball found herself reading the worth of her hosts through their homes. Describing one of her more colorful hosts, Kimball wrote, "Her house was certainly not clean, her children were disagreeable her husband a horsethief." Although she complained that one family was "quite poor and she was not very neat," she commented that another family

9. Kimball Diary, 1 February 1862.

10. Ibid., 1862, p. 52. 
who "lived in a very small house one room below and one above, were very poor, but were good and I liked to go there." After staying with another family of "poor folks," she remarked, "There was an air of refinement about them and they seemed like a family that had seen better days." ${ }^{\prime 11}$

While Kimball's definition of "good" included poor people, her diaries still reflect a clear preference for the homes that could only be created with some degree of wealth. Describing one family, she wrote, "the house was surrounded by trees and a beautiful green lawn.... They were very neat people and every thing in and about the house was kept in order." After spending the night with the school superintendent's family, she wrote, "They lived in a large house very well furnished. ... Mrs. Niles cultivated some shrubbery ... and every thing around had the appearance of comfort and home happiness. ${ }^{\prime 12}$

"Home happiness" was surely the best compliment possible for a woman participating in the "cult of domesticity." Merely having money or large houses was not sufficient to achieve home happiness, however. As Kimball recorded of another family, "they lived in a framed house on a high hill but the place was destitute of trees or flowers. ... there was something lacking in the house as well as around it." Similarly, neatness without attention to furnishings and decorations would not bring Kimball's admiration. The Johnsons "live in a large frame house ... surrounded with weeds but no trees flowers or pretty green grass. They seemed cold and distant to me. ... they were very neat and orderly people but their house had the same appearance that they did. There was too much stiffness about it."

Clearly, Kimball's understanding of class was very much in keeping with a recent scholarly understanding of the emergence of the middle class. The middle class, according to this interpretation, should be understood not in strictly economic terms, but more as an ideological, or imagined, community. People were middle class not because of how much money they did or

11. Ibid., 1863 (p. 86) 1864, (p. 121), 1862 (p. 51), 1864 (122).

12. Ibid., 1864 (p. 122-23), 1863 (p. 87).

13. Ibid., 1864 (pp. 123, 124). 
did not have, but because they thought they were middle class, and shared certain habits and beliefs. ${ }^{14}$

By the time Kimball was through teaching, she had visited dozens of homes and had a vision of what constituted a proper home. She came to believe that the state of a person's home defined the status of the individual. She could recognize "home happiness" when she saw it, and she knew the importance of not just money and neatness, but also decoration. In defining the imagined "middle class," Kimball called upon not just abstract markers, but concrete visual cues. Her experience suggests that rural schoolteachers, through their exchange throughout various communities, might have been crucial in the formation of a coherent rural middle class, particularly on the prairie frontier. As Kimball and other traveling teachers moved from home to home, they were both receiving and spreading ideas about class and domesticity, providing connections and continuity between otherwise spread-out and isolated farm communities.

Unfortunately, Kimball's illness (which was apparently never diagnosed and whose symptoms she never fully describes) was just beginning in 1865 . Over the next several years, it regularly interfered with her active social life and confined her to home more than she might have liked. Eventually, after the winter term of 1870/71, she decided to quit teaching because "my health is miserable." She knew she would miss teaching but concluded that "it is better that I should stay at home and help them here"- a prospect that the diary entry quoted earlier suggests must not have been appealing. ${ }^{15}$

It was during the years of her illness that Kimball turned to fancywork - the creation of the various handmade items so prominently featured in her parlor photographs such as the garlands, dioramas, wood cutouts, and elaborately constructed seed and cone picture frames. Her efforts made a significant contribution to the Kimball family's emergence into the middle class. At a time when the American middle class was emerging

14. Stuart Blumin, The Emergence of the Middle Class: Social Experience in the American City, 1760-1900. (Cambridge, 1989).

15. Kimball Diary, April 1871. 
as a distinct idea and community, many families used fancywork to help distinguish themselves as "middle class."

Material culture is a key indicator for identifying members of the "middle class." In the mid-nineteenth century, profusely decorated parlors (or the lack thereof) helped to differentiate between families that made a claim to the middle class and those that did not. According to Stuart Blumin, the parlor served as "the arena within which the aspiring middle classes worked to establish their claims to social status." Because women played such a key role in creating and maintaining these formal parlors, Blumin concludes that "the emergence of a distinct middle class was closely connected with, and largely dependant upon, the development of the domestic ideal." Nancy Bercaw adds, "In cultivating good taste and filling their homes with edifying objects, these diverse fancywork makers helped create the appearance of a common culture and an open society or, as we now refer to it, the nineteenth-century middle class." People have always distinguished themselves from others in their culture by what they own. What is unique about fancywork is that women could decorate their parlor in the latest fads without having to buy the objects. Thus Kimball could situate herself in the middle class when she otherwise did not have the economic means to do so. Through fancywork Kimball made her middle-class home. ${ }^{16}$

Other changes in the consumer culture contributed to the popularity of fancywork: the national accessibility of small consumer goods, such as beads and glue, the availability of fancywork patterns through the emerging popular press; and the simplification of certain needlework techniques. Thus Kimball, and other women on the frontier and in America's growing cities, were able to surround themselves with fashionable new consumer goods before they could readily purchase them. ${ }^{17}$

The creation of fancywork was only half of the equation for women hoping to join the middle class. Fancywork should not just be made; it also must be properly displayed. Decorative conventions of the time led women to display their fancywork

16. Blumin, Emergence of the Middle Class, 160, 184, 187; Bercaw, "Solid Objects / Mutable Meanings," 234-39.

17. Harvey Green, The Light of the Home: An Intimate View of the Lives of Women in Victorian America (New York, 1983), 1. 
in what one scholar has called "bricoabracomania. ${ }^{118}$ Kimball's three parlor portraits show what we might now see as a cluttered array of knick-knacks. The walls are covered, every inch of table space is used, and her wood cut-outs lean against other objects on the floor. As the production and ownership of fancywork had come to be a sign of middle-class respectability, the parlor was specifically designated as the site for public display, and was the centerpiece of most women's decorative efforts. Unlike modern conventions that often call for a more sparse decorative style, middle-class parlors in the second half of the nineteenth century were stuffed to overflowing. If one garland was good, four were better. The women and men of the nineteenth century did not look at their parlor and see homemade clutter. They saw the trappings and evidences of a wellestablished middle-class family. Kimball considered her parlor to be worthy of portraiture, and the Artist Lee's photographs give as much attention to the parlor as to the people who owned it.

SARAH JANE KIMBALL'S FANCYWORK not only played an important role in placing her family firmly within the middle class on the basis of their material environment; it also helped her create her self.

By the time she quit teaching in 1871, Kimball was 32 years old and knew no young men who interested her. She had begun teaching at a time when most of the young men in Jones County had left to fight in the Civil War. In 1865, as the war ended and the men returned home, a flurry of marriages had occurred throughout Iowa (as well as the rest of the United States), which Kimball missed due to her illness. She had been interested in one man, Joe Edwards, before he went to war, and corresponded with him during his service, but following the war he went to California to seek his fortune. It is unclear from Kimball's diaries whether the love was unrequited or if Kimball was

18. Bradley C. Brooks, "Clarity, Contrast, and Simplicity: Changes in American Interiors," in The Consumer Culture and the American Home 1890-1930: Proceedings of the McFaddin-Ward House Museum Conference, October 27-29, 1988, ed. Glenda Dyer and Martha Reed (Beaumont, TX, 1989), 20-21. 
unwilling to leave her family and her beloved Iowa. Always reserved in her writing, Kimball gave practically no details of their relationship at the time that it occurred, the details dribbling out over the following years in very brief asides in her diaries. Although she consistently hid her emotions, she continued to write of dreams of Joe until she was well into her forties. One entry states, "Last night I dreamed I was being married to Joe by O. E. Aldrich. It seemed so real. ${ }^{\prime 19}$

The late 1860s, then, were difficult years for Kimball. Chronically ill, she lived out the remainder of her life in her parents' home; she never married, and after she abandoned her teaching career, she never again worked and lived independently. By the end of the 1860s, though, Kimball was apparently able to create a satisfying, meaningful life for herself. After she turned 30, Kimball defined who she was and who she would be without having access to the standard roles for frontier women: wife, mother, or teacher. In her search for meaning and identity, she turned to fancywork.

Kimball was not alone in the nineteenth century in deriving meaning and identity from the objects she created. Scholars who study the interplay between objects and culture (material culture) recognize that not only do objects assist people in their construction, development, and representation of the self, but an individual can literally get a sense of self from living in a material universe with a certain symbolic meaning, such as a home filled with family heirlooms. ${ }^{20} \mathrm{We}$ are, in this way of seeing the world, what we own-not in the shallow sense of being judged by others for what we own, but in the more subtle sense that we understand ourselves as being the owners of particular types of objects. One person, for instance, might own collections of fine art and antique furniture, while another might own collections of sports posters and jazz recordings; for both people, their possessions both reflected and shaped who they were.

19. Kimball Diary, 16 September 1877.

20. Virginia Dominguez, "The Marketing of Heritage," American Ethnologist 13 (1986), 553; Grant McCracken, Culture and Consumption (Bloomington, IN, 1988). See also Mihaly Csikszentmihalyi and Eugene Rochberg-Halton, The Meaning of Things: Domestic Symbols and the Self (Cambridge, 1981), 14-15. 
In the mid-nineteenth century, fancywork had a specific set of associations as well, associations centered on women's role within the family and home. Fancywork included a wide variety of (almost exclusively female constructed) handmade crafts. What made it fancywork, however, was that it was "ornamental as opposed to plain work." Chores such as making needed household textiles and goods had always been an essential part of many households' domestic economy. Fancywork was different: it was purposefully ornamental in nature and involved such activities as sewing, stitching, or making "sculptural forms in shell, wax, molded leather, pine cones, fish scales, cardboard," or any other materials handy.

As early as the 1840s, fancywork had achieved widespread popularity among women from all regions of the United States. It was popular in state and county fairs, magazines, and homes from New York to St. Louis. Its popularity would continue nearly unabated through the 1880 s until finally fading in the $1890 \mathrm{~s}^{22}$ Even though Kimball had stopped producing fancywork decades earlier, she still proudly displayed her fancywork in 1899.

Fancywork's popularity coincided with the changing image of the ideal American home. The last half of the nineteenth century was a period of enormous social and political change. These fifty years saw the Civil War, growing industrialization and urbanization, the closing of the frontier, a phenomenal burst of immigration, and a burgeoning labor movement. In response to these and many other changes, a number of reform movements and ideologies of social improvement began to find expression in the immediate post-Civil War period. Some of these reform ideologies centered around what later came to be called the "cult of domesticity," an emphasis on women's role within the home and family as a source of moral enlightenment. Within this context, "the atmosphere of the home was seen as

\footnotetext{
21. Beverly Gordon, "Victorian Fancy Goods: Another Reappraisal of Shaker Material Culture," Winterthur Portfolio 25 (1990), 116; Joanna Stratton, Pioneer Women: Voices from the Kansas Frontier (New York, 1981), 69; Beverly Gordon, "Victorian Fancywork in the American Home: Fantasy and Accommodation," in Making the American Home, ed. Marilyn Ferris Motz and Pat Browne (Bowling Green, OH, 1988), 48.

22. Bercaw, "Solid Objects/Mutable Meanings," 237.
} 
having an almost mystical effect on its inhabitants, determining their moral standards, happiness, and success in the outside world." Creating and maintaining this all-important "atmosphere of the home" was seen as a woman's job, and fancywork was one of the tools women could use to decorate their homes and improve their family environment. Kimball's pine cone picture frames, for instance, "manifested qualities of the natural world and brought its edifying lessons into the family parlor." In creating fancywork, many Americans believed that women were actually preserving society in the face of the dramatic changes of the era. ${ }^{23}$

In addition to providing the proper enlightened ambience that would enable family members to achieve success in the outside, public world, fancywork also played an important stabilizing role in the private sphere of family morality and refinement. Fancywork enabled women to provide refined surroundings cheaply, and to tailor the home environment to the specific history and values of her family. The handmade nature of fancywork also emphasized the woman's production of goods, as opposed to merely selecting her decorations from a catalog. And, not least, many women enjoyed creating fancywork. Fancywork not only fulfilled a crucial social role; it also allowed women the freedom of self-expression. Indeed, "many women deliberately cultivated the image of being an artist to increase the public stature of their position in the house." Fancywork allowed "women who sewed objects for their homes [to], in a very real sense, ... stitch together those environments, making their houses into homes and infusing them with their own energy, good taste, and positive influence. ${ }^{124}$

23. Ibid., 233, 231; Marilyn Ferris Motz, "Introduction," in Making the American Home, ed. Motz and Browne, 1; Clifford Edward Clarke Jr., The American Family Home, 1800-1960 (Chapel Hill, NC), 35; Gordon, "Victorian Fancywork," 55.

24. Shirley Teresa Wajda, "The Artistic Portrait Photograph," in The Arts and the American Home, 1890-1930, ed. Jessica Foy and Karol Ann Marling (Knoxville, TN, 1994), 168; Angel Kwolek-Folland, "The Useful What-Not and the Ideal of Domestic Decoration," Helicon 8 (1983), 72; Gordon, "Victorian Fancywork," 64; Clarke, American Family Home, 107; Beverly Gordon, "Cozy, Charming, and Artistic: Stitching Together the American Home," in The Arts and the American Home, ed. Foy and Marling, 126. 
It was a particular challenge to make a house into a home on the frontier. When the Kimball family moved to Iowa in 1856, they were part of Iowa's first wave of large-scale immigration. A relatively new state (ten years old in 1856), Iowa was still very much part of the American frontier. The Kimballs began their life in Iowa on their Jones County homestead with 180 acres, no house, and no improved land. Obviously, for this family (and so many others like them), their home "was not the quiet and cozy retreat that nineteenth-century culture envisioned, but a busy center of endless chores and economic ventures." ${ }^{\prime 25}$

Prairie women (and men) were generally aware of prevailing cultural attitudes regarding women and the cult of domesticity; it simply was not always practical to achieve the ideal. Like many other frontier women, Kimball had to assume a heavy burden on the family farm. In addition to tending vegetable and flower gardens, looking after her five younger siblings, and helping her mother with cooking and cleaning-all traditional women's chores-she assumed sole responsibility for the chickens (including largely building their pen herself) and milked the cows. These tasks seemed incongruous with, and left little time for, cultivating urban, middle-class ideals of domesticity.

Although the frontier presented obstacles to typical expressions of domesticity, frontier women did not reject those ideals. ${ }^{26}$ Many women felt that in the absence of pre-existing (EuroAmerican) civilization, which they could preserve and inculcate by maintaining the proper domestic atmosphere, it was their duty to create the American family home on the frontier. Thus fancywork, though commonly thought of as an urban phenomenon, might have been readily accepted and practiced by frontier women dedicated to the conscious creation of refined culture in their homes.

25. Julie Roy Jeffrey, Frontier Women: The Trans-Mississippi West, 1840-1880 (New York, 1979), 61. See also Carol Fairbanks and Sara Brooks Sundberg, Farm Women of the Prairie Frontier: A Sourcebook for Canada and the United States (Metuchen, NJ, 1983), 50, 52.

26. Jeffrey, Frontier Women, 12, 73. At the outset of her research on frontier women, Jeffrey had "hoped to find that pioneer women used the frontier as a means of liberating themselves from stereotypes and behaviors which I found constricting and sexist" (xv-xvi). Ultimately, however, she found that frontier women did not reject ideas of domesticity. 
Kimball, as an 18-year-old diarist, was more concerned with writing romantic poetry than with the physical details of building a home. Her poetry, often sentimental, placed Kimball firmly within the larger nineteenth-century culture of domesticity. At the same time, the details of day-to-day life that she recorded in her journal place the family firmly within the frontier context, detailing the frantic completion of their first home and the cold nights sleeping next to tar-paper windows. By 1865 , though, Sarah Jane no longer wrote poetry (or at least, no longer recorded it in her diary), and the Kimballs no longer had to worry about building a home or a farm. By that time the substantially improved Kimball home needed to be decorated in an edifying and appropriate manner; it needed, in the parlance of the time, a woman's touch.

Kimball used fancywork to decorate her family's home and to conform to the dictates of domesticity. In so doing, she was also actively creating her own sense of identity when decorating the family parlor. Fancywork, as a homemade craft, was not just decoration; it was also the expression of an individual artistic vision. Beyond simply representing the self in fancywork, or being judged by others on the basis of fancywork produced, women engaged in the production of fancywork were producing themselves. They were defining themselves in relationship to nineteenth-century domestic culture as "good women," as artists, and as morally superior. Even if it was a product of larger cultural forces, fancywork was self-definition; women had a great deal of autonomy in the personal choices of their respective decorations and creation. ${ }^{27}$

This understanding of fancywork as at least partially, if not primarily, an act of self-creation provides a context for understanding Sarah Jane Kimball's burst of creative activity during the postwar period, when Kimball ultimately gave up on the possibilities of both a teaching career and marriage and a family of her own and instead moved back in with her family. Fancywork represented an opportunity for Kimball to actuate herself in a period of personal flux, and she embraced the opportunity.

27. Bercaw, "Solid Objects/Mutable Meanings," 233, 243; Susan Arpad, "Pretty Much to Suit Ourselves: Midwestern Women Naming Experience through Domestic Arts," in Making the American Home, ed. Motz and Browne, 13. 
After briefly mentioning that she was learning to sew on a borrowed sewing machine, Kimball began to create cloth pictures; in August 1866 she "Cut out a rooster, also a bouquet." On September 15 she noted the display of one of her creations, writing that "I have cut a cat out of cloth and hung it up. I think it looks quite natural." From there, her fancywork became more and more ornate. In the following three years, Kimball described making "a case of birds," a chair, numerous pin cushions, a bookcase covered with paper, ornamental cases for rocks, moss, and shells, an "air castle made of straw," and numerous frames covered with corn, plum pits, and shells. After making a box and filling it with her "childish playthings," she decided to frame it to remind her of "happy days long gone by." As every nook and cranny of the house filled up with Sarah Jane's fancywork, her journals reflected less anxiety about living at home with her mother and a generally more optimistic outlook about a life at home. Perhaps Kimball's fancywork during this period made her difficult decision to give up on an independent life of teaching an easier one. ${ }^{28}$

Kimball's fancywork served several purposes. Most simply, the display of fancywork in the home indicated that the house was at least partially Sarah Jane's, not just her mother's. Kimball had assumed the primary role of "home creation." While her mother retained the primary responsibility for cleaning the home, Kimball had claimed the cultural and moral high ground; her "womanly" influence and her fancywork shaped the home environment, making it largely her home. This dynamic accelerated in the 1870s as Sarah's mother became increasingly feeble. Fancywork helped Kimball define herself as a civilizing influence on the prairie, a useful member of the family, and an "artist" (a designation she bore until her death, when an anonymous biographer spoke of her wondrous dioramas). ${ }^{29}$

28. Kimball Diary, 2 August and 15 September 1866, September 1868 (p. 215), November 1868 (p. 219), April 1866 (p. 208), November 1866 (p. 163), October 1867 (p. 187), January 1867 (p. 171).

29. Anonymous biography, Kimball Papers. 
AFTER HER INITIAL FLURRY OF ACTIVITY in the latter half of the 1860s and the early 1870s, Kimball never again was to produce fancywork so prolifically. Occasionally she recorded the creation of a piece of art, but she spent more of her energy on floriculture and raising birds (a kind of living fancywork). Kimball had enjoyed keeping flowers and birds even while teaching, but she could pursue both hobbies more easily when living permanently at home than she could as an itinerant teacher. Once living at home, and as she spent more time on her birds and flowers (and on her nearly constant round of social visitations), Kimball's fancywork production slowed down. Her fancywork was still on display in the 1899 photographs, however, indicating that Kimball, having established a fancywork definition of herself and of her home with which she was comfortable, maintained this environment for at least 30 years.

Nonetheless, fancywork is not all we see. Many of the objects prominently displayed in Kimball's parlor are not handproduced crafts or art. The national catalog culture is visible throughout the parlor. On the table there is a stereoscope surrounded by slides. A melodeon rests in the corner. The pictures on the wall are not handmade, or even local. Perhaps most significantly, in one of the three portraits of the family, Sarah Jane is holding a stereoscope-a purchased object bearing no relationship to her fancywork or art.

Although Kimball had owned a melodeon since 1865 and a stereoscope since 1868, she had purchased other objects that occupied the parlor more recently. As the nineteenth century came to a close, Kimball wrote of ordering goods from catalogs far more frequently than she wrote of doing fancywork. She even purchased artistic objects, such as a "Columbus ship wall hanging," that she once might have made herself. ${ }^{30}$ With the advent of Rural Free Delivery in 1896 and department stores' aggressive marketing, Kimball's shift from fancywork to catalog consumption once again reflected larger rural and national trends.

Does it make any difference whether people define themselves by purchased or created objects? Some material culture scholars juxtapose the emergence of American consumer cul-

30. Kimball Diary, 17 May 1896. 
ture, and people's understanding of themselves as consumers, to a "purer past" when people like Sarah Jane did not purchase their material identity but created it. ${ }^{31}$ But Kimball was never purely a producer any more than she became purely a consumer. Admittedly, there does seem to be a change midway through the last half of the nineteenth century as Kimball created less fancywork and ordered more of her later decorations from catalogs. This should not surprise us. There were more things available for purchase at the end of the nineteenth century than in 1850, and more people could and did buy them. Still, even Kimball's earliest fancywork reflected important aspects of mass consumer culture. She expressed relief when her order of "wood varnish, putty, and lye" arrived from a national store in $1868 .^{32}$ And many women used patterns published in national magazines to create their fancywork. Fancywork could even be bought in many stores. (Apparently the Shakers made a substantial income from selling fancywork). ${ }^{33}$ And clearly people purchased objects to mark their class status long before the end of the nineteenth century. Objects such as silver platters (obviously consumer items) have been important as class markers and as self-defining objects for centuries.

THE PHOTOGRAPHS that Sarah Jane Kimball ordered in 1899 present a parlor, a life, and a culture in transition. Between her first journal entries in the 1850s and her visits with the "Artist

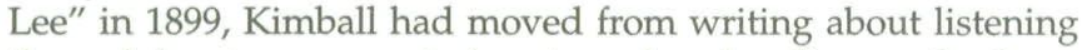
through her tar-paper window to wolves howling on the Iowa prairies to posing next to a melodeon, from writing about an

31. For the glorification of handmade crafts and the "arts and crafts" movement, see, for example, Sigmund A. Lavine, Handmade in America: The Heritage of Colonial Craftsmen (New York, 1966); and Lionel Lambourne, Utopian Craftsmen: The Arts and Crafts Movement from the Cotsworlds to Chicago (Salt Lake City, 1980). For critiques of nostalgic notions about the relationship between handiwork and consumption, see, for example, William Leach, Land of Desire: Merchants, Power, and the Rise of a New American Culture (New York, 1993); and Colin Campbell, The Romantic Ethic and the Spirit of Modern Consumerism (New York, 1987).

32. Kimball Diary, December 1868 (p. 225).

33. Gordon, "Victorian Fancy Goods," 111-12. 
Iowa very much on the American frontier to being photographed in a definitely middle-class American home. Fancywork had helped Kimball define herself as more than the net sum of her circumstances. It had also helped her create a middleclass home when the family did not have enough money to purchase such trappings. If Kimball had possessed the necessary money, however, could she not have achieved similar results through catalog consumption? Indeed, as soon as she did begin to acquire disposable income, she spent it on consumer items such as her stereoscope and melodeon. ${ }^{34}$ Kimball's parlor expresses her transition from an artifact creator to a catalog consumer. That transition reflects a shift across Iowa and across the country toward a new century of unprecedented mass consumption and material wealth. Despite nostalgic notions suggesting that a self defined by handiwork is somehow superior to one defined by consumption, it is not at all clear that Kimball would (or that we should) see this transition as a material culture fall from grace. Contemporary attraction to handmade objects as markers of quality, prestige, and wealth (for they are usually far more expensive) does not translate well into the late nineteenth century, when the novelty of industrial products was sweeping across America.

Sarah Jane Kimball used fancywork to negotiate a position for herself within her family and larger culture, but her parlor was never, truly, the self-made parlor of our nostalgic myth. Instead, fancywork for her parlor was Kimball's way of stitching together meaning in her life by conforming to prevailing ideologies of domesticity and class. By 1899, Kimball apparently believed that she could express and define herself as much by buying a gilded mirror from Sears \& Roebuck as she could by making frames of peach pits and pine cones.

34. In fact, Kimball purchased her first stereoscope in 1868, with savings from her teaching positions, in the midst of her most prolific period of fancywork production. Kimball Diary, October 1868 (p. 217). 
Copyright of Annals of Iowa is the property of State of Iowa, by \& through the State Historical Society of Iowa and its content may not be copied or emailed to multiple sites or posted to a listserv without the copyright holder's express written permission. However, users may print, download, or email articles for individual use. 